\title{
The Virtue of Piety in Medical Practice
}

\author{
David McPherson
}

\begin{abstract}
Following the Introduction, the second section of this essay lays out Tom Cavanaugh's helpful and convincing account of the enduring significance of the Hippocratic Oath in terms of how it responds to the problem of iatrogenic harm. The third section discusses something underemphasized in Cavanaugh's account, namely, the key role of the virtue of piety within the Oath and the profession it establishes, and argues that this virtue should be regarded as integral to an authentic Hippocratic ethic. The fourth and final section briefly examines the connection between medicine and philosophy, focusing on how both should be seen as wisdom-seeking ways of life, and shows the relevance of this for regarding the virtue of piety as the key virtue of medical practice.
\end{abstract}

Keywords Hippocratic Oath - Piety - Virtue - Sanctity of Human Life - T. A. Cavanaugh

“... purely and piously I will watch over my life and my art."

-The Hippocratic Oath (tr. T. A. Cavanaugh in Cavanaugh 2018: 154)

\section{Introduction}

In Hippocrates' Oath and Asclepius' Snake: The Birth of the Medical Profession, Tom Cavanaugh provides a rich and illuminating exploration of the Hippocratic Oath; both in terms of its historical genesis and its enduring significance for medicine. I am fundamentally in agreement with Cavanaugh about the enduring significance of the Hippocratic Oath. However, I want to discuss a feature of it that is underemphasized but which I maintain is of great importance for medical practice today: namely, the centrality of the virtue of piety. In the second section of this essay I will lay out Cavanaugh's account of the enduring significance of the Hippocratic Oath. In the third section I will discuss the role of the virtue of piety within the Oath and the profession it establishes and argue that this virtue should be regarded as integral to an authentic Hippocratic ethic. In the fourth and final section I will briefly examine the connection between medicine and philosophy, focusing on how both should be seen as wisdom-seeking ways of life, and I will show the relevance of this for regarding the virtue of piety as the key virtue of medical practice.

\section{The Problem of Iatrogenic Harm and Hippocrates' Oath}

The foundational medical-ethical problem to which Hippocrates' Oath seeks to respond, Cavanaugh contends, is "the problem of iatrogenic harm," and this response "inaugurates medicine as a profession" (2018: 2-3; cf. 18-30). Harm that is iatrogenic - from the Greek iatros, meaning "physician," and genos, meaning "born of" - is harm that is caused by a physician, and it can take three forms: First, there are wounds that are ineliminable from the work of healing (e.g., cauterizing to stop bleeding). Second, there are harms that are the result of physician error (e.g., giving the wrong dose of a drug). Lastly, there are "wounds of role- 
conflation" (e.g., euthanizing a patient or assisting in suicide): "In the last type of wound (the most problematic), a physician adopts the role of wounder by deliberately injuring, thereby abandoning the practice of medicine as an exclusively therapeutic activity" (2). While ethical medicine should certainly seek to minimize harms that result from physician error as far as possible, Hippocrates' Oath, Cavanaugh maintains, responds above all "to the profound threat role-conflation poses to medical practice": "By means of the Oath, Hippocrates ... founds medicine as a profession devoted wholly to therapy, explicitly excluding deliberate wounding" (ibid.).

First of all, those who take the Hippocratic Oath solemnly pledge to act "for the benefit of the sick" to the best of one's ability, and regard this as the proper end of medicine (56-57). Second, and relatedly, the Oath forswears deliberately causing harm, and specifies three major types of harm to be avoided: intentional killing, sexual exploitation, and violating confidence (57-69). The Oath does not offer comprehensive ethical guidance, but rather it "establishes boundaries within which ethical medicine takes place" (4). As Cavanaugh points out, "Horkos, the Greek word for 'oath,' is related to herkos 'fence, that which encloses"' (43; cf. 127-128). The act of taking the Oath establishes medicine as a profession with its own internal ethic centered on "the golden medical rule": help and do no harm (3, 121-134, 139-140). This means that medicine cannot be regarded as a morally neutral skill (or know-how) that can be used for diverse and incompatible ends (3, 23-25, 74-77, 123-124, 141-143). Hippocrates' Oath, we might say (though Cavanaugh does not put it this way), regards medicine as morally special (rather than morally neutral) because it responds to a situation that is morally charged: an encounter with a sick person who is vulnerable and in need of medical help, and sometimes this need is particularly dire, where life itself and not just health is at stake. In taking the Oath one publicly and solemnly professes before all of those who may find themselves in this condition which is all of us - that he or she is there to help and not to harm and so can be trusted to care for our medical need.

\section{The Virtue of Piety in Medical Practice}

As aforementioned, I am in agreement with Cavanaugh about the enduring significance of the Hippocratic Oath, and I find his discussion of it illuminating and largely persuasive. However, I think he underemphasizes the role of piety within the Hippocratic ethic.

This is not to say that Cavanaugh gives no attention to the role of piety within the Oath. In Chapter 2 of the book he examines each part of the text of Hippocrates' Oath, and so he discusses how it begins with swearing by gods and goddesses (43-49), and later he mentions that people taking different versions of the Oath today will often swear by God or whatever they regard as sacred (126). This communicates and establishes the seriousness and solemnity of what one is undertaking in the practice of medicine. Cavanaugh also discusses the part of the Oath where Hippocrates explicitly mentions piety, which is the following passage:

I will neither give a deadly drug to anyone, though having been asked, nor will I lead the way to such counsel; and, similarly, to a woman a destructive pessary I will not give. But purely and piously I will watch over my life and my art.

This is, not surprisingly, the most controversial passage of the Hippocratic Oath today, since it takes a stand on several major moral controversies: The Hippocratic physician is not to euthanize or assist in suicide and is also not to kill unborn human life. Cavanaugh notes that forswearing of 
euthanasia, assisted suicide, and abortion in the Oath "cannot be understood absent the juror's concluding reference to purely and piously guarding his life and art":

The Greek word for "purely" (hagnos), coming as it does after reference to not giving a deadly drug and not giving a life-destroying abortive, indicates that the Oath here addresses purity from blood-guilt. That is, the oath-taker forswears killing and thus will be pure before all the gods and goddesses in this respect ... This sense of being free from blood on one's hands before the gods becomes even more pronounced when one considers the complementing word for that here translated as "piously," hosios. ... Dikaios refers to human justice; hosios refers to righteousness before and with the gods. (58-59)

Cavanaugh goes on to remark: "[The] Oath features a religious sensibility that forswears killing (including inchoate human life)" (60).

So why do I say that Cavanaugh underemphasizes the role of piety in the Hippocratic ethic? I say this because when he comes to defend the continuing validity of the Oath's prohibition of intentional killing in Chapter 3, the religious sensibility and any reference to piety drops out. However, I want to contend that a religious (or at least a quasi-religious) sensibility that gives recognition to the sacred or the reverence-worthy is crucial for the viability of the Hippocratic ethic. The virtue of piety, as I understand it, is the virtue of being properly responsive to what is sacred or reverence-worthy, which includes human life. Piety also seeks to be properly responsive to the sources of our lives, such as our parents (hence we can speak of filial piety) and God or the gods (hence we can speak of religious piety). ${ }^{1}$ Being properly responsive here will involve showing reverence for human life and its sources, which includes recognizing claims of inviolability with respect to human life, since what is sacred is set apart in placing boundary markers upon what we are allowed to do with respect to it: for instance, we are not allowed to destroy human life intentionally; this is absolutely ruled out. It should be noted that although I am following Cavanaugh in speaking of a "religious sensibility" here, one does not need to be religious in any traditional sense (e.g., being a theist) in order to accept this sensibility. What is required is an affirmation of the reverence-worthiness of human life, where this is understood as setting limits upon our will. Hence, I think we can also speak of a quasireligious sensibility here. ${ }^{2}$

\footnotetext{
${ }^{1}$ Cora Diamond writes: "The notions of piety and impiety are complex ... One part of the notion of piety is the idea that we should treat the natural order of things with respect and awe. Another element is the idea of respect and gratitude as due to the sources of our life, which may be conceived to be God or the gods, our parents and ancestors, and our country. Another part of the notion of piety is the idea that actions that violate piety are properly regarded as outrageous or shocking. This outrage may manifest a sense that a wholly wrongful posture has been exhibited, a kind of will to dominate the natural order, a refusal to accept limitation, a challenge to God's sovereignty or to honored and honorable traditions that should be taken as sacred" (2017: 31). See also Roberts 2017 for a helpful discussion of filial piety and religious piety.

${ }^{2}$ For more on these matters see McPherson 2020: 91-104. I am dealing here at the level of moral phenomenology (or sensibility), and it is then a further question - which I am not exploring - of what worldview might best support the moral phenomenology of the sacred or the reverence-worthy. Since I am not saying here that one has to believe in God or the gods in order to affirm the virtue of piety, my argument does not raise the "Euthyphro problem" (from Plato's Euthyphro) of whether God (or the gods) loves piety because it is pious, or whether it is pious because it is loved by God (or the gods). My own view is that a theist should say that God loves piety because it is pious, that is, because it is inherently good or excellent (the other option makes morality arbitrary). I don't think this makes God irrelevant for morality - as is often supposed - for four main reasons that a theist can affirm: First, God creates the world in light of a perfect understanding of the good and as ordered toward realizing this good. Second, God perfectly exemplifies the good, such that we can say that God is good (or the
} 
The main reason that Cavanaugh provides for upholding the Oath's prohibition of intentional killing by physicians is that "one cannot care for another by destroying that other, even at his request": "Therapy, caring for a subject, requires the subject to exist so that he may receive one's care. ... Killing performed by a doctor is oxymoronic, a practical contradiction" (85). ${ }^{3} \mathrm{He}$ also provides five additional reasons for why physicians ought not to kill: First, killing by physicians undermines patient trust, and it renders "ambivalent the deaths of patients that do at times occur in the normal practice of medicine" (99). Second, killing by physicians can wrongly medicalize existential distress: "To lack control over the time and manner of one's death partially defines the human condition. To regard this lack as a disease in need of a healer's treatment errs fundamentally" (101-102). Third, killing by physicians "jeopardizes the welfare of vulnerable others, rendering them, too, susceptible to this injury": "By killing or assisting in the killing of a patient, a physician indicates to reasonable others that having that disorder is a good reason to be killed by one's self or others. ... By assisting a patient's suicide or by euthanizing a patient, a doctor suggests that killing solves human trials and tribulations" (102103). Fourth, "recourse to killing will retard the development of medicine as an art" (104). Fifth, and lastly, "by killing even in a putatively therapeutic manner, the physician undermines medicine's ability not to be suborned into killing more generally and for diverse purposes" (ibid.).

I am sympathetic with all of the reasons given here, but what is striking is what is not said: namely, that physicians ought not to kill because it violates the sanctity of human life and so would be impious. Without this, I want to explain, there is a difficulty of absolutely ruling out killing by physicians. In his discussion of the wrongness of killing by physicians in Chapter 3, Cavanaugh seems to be operating too much within the prevalent disenchantment of our times, which does not recognize the realm of the sacred (or the reverence-worthy) and so lacks a crucial conceptual resource for making sense of absolute prohibitions. ${ }^{4}$ Hippocrates' Oath, as Cavanaugh makes clear in Chapter 2, is not operating within such a disenchanted outlook, and in his defense of the Hippocratic ethic I think Cavanaugh needs to do more to resist this disenchanted outlook by defending something like what he describes as the Oath's "religious sensibility that forswears killing (including inchoate human life)." Such a religious sensibility (or at least quasi-religious sensibility) that gives recognition to the sacred or the reverence-worthy, I contend, is in fact constitutive of a Hippocratic conception of the medical profession.

Consider again Cavanaugh's main reason for opposing killing by physicians: "Therapy, caring for a subject, requires the subject to exist so that he may receive one's care. ... Killing

Good). Third, our responsiveness to God's grace enables us to realize the good more fully in our lives. Finally, God perfectly loves the goodness that is inherent in the world, including in humanity, and in doing so helps to make manifest this goodness to us. See McPherson 2018: 94-96.

${ }^{3}$ Leon Kass similarly remarks that there can be "no benefit without a beneficiary" (2002: 34). But earlier he also comments: "For the [Hippocratic] physician, ... human life in living bodies commands respect and reverenceby its very nature. ... The deepest ethical principle restraining the physician's power is neither the autonomy and freedom of the patient nor the physician's own compassion or good intention. Rather, it is the dignity and mysterious power of human life itself, and, therefore, also what the Oath calls the purity and holiness of the life and art to which the physician has sworn devotion" (32).

${ }^{4}$ The virtue of piety is overlooked in the most prominent defense of a virtue ethic approach to medical practice, namely, Pellegrino and Thomasma 1993, which discusses the following list of virtues: fidelity to trust, compassion, prudence, justice, fortitude, temperance, integrity, and self-effacement (Hippocrates' "exhortation to lead a 'pure, holy' life" is mentioned on p. 184, but this is not explored, let alone defended; though the Hippocratic tradition is defended). The same is also true of Pellegrino and Thomasma 1996, which discusses the "theological virtues" of faith, hope, and charity in the context of medical practice. 
performed by a doctor is oxymoronic, a practical contradiction." This makes sense if we have already accepted the Hippocratic conception of the medical profession with its particular view of what caring or healing consists in, including what limits or "fences" should be put around it. But, as Cavanaugh acknowledges, there are rival conceptions of the medical profession with different views of the healing mission. In particular, he discusses "Apollonian" and "Asclepian" conceptions of the medical profession as rivals to the Hippocratic conception. He writes: "[The] Apollonian physician will harm outright when doing so putatively reduces overall harm. ... The Apollonian physician's injuring in order to reduce harm assumes a divine character ... The Asclepian includes killing (and thus acts somewhat divinely) while proposing that it is not injurious, but, rather, beneficial" (76). In other words, Apollonian and Asclepian physicians "play God" in not accepting any fundamental limits on what one can do in order to reduce suffering; they only disagree on whether killing in order to reduce suffering is to be described as a necessary injury or as in fact a benefit. (We don't have to agree with the implicit theology; indeed, I think any God worthy of worship would not intentionally take innocent human life). Here we have conceptions of healing that are centered on reducing suffering and promoting quality of life. If someone is terminally ill and suffering greatly, such views would regard euthanasia and assisted suicide as forms of "healing." In addition to quality of life conceptions of healing, there are also autonomy-centered conceptions of healthcare that are primarily concerned with respecting people's autonomous choices with regard to their healthcare, which may involve deciding to be euthanized (or to be assisted in suicide) or to undergo an abortion procedure. So, the question that needs to be addressed is the following: Should the practice of medicine be centered on quality of life (or suffering-reduction), autonomy, or the sanctity of human life?

The Hippocratic ethic is best understood as being guided by the sanctity of human life (and so also by the virtue of piety), which makes demands both for treatment that helps to restore someone to bodily health as far as possible and to avoid "playing God" by intentionally harming, including, above all, killing. ${ }^{5}$ This forms the basis of the practice of oath-taking that constitutes medicine as a profession within the Hippocratic outlook. Indeed, Cavanaugh discusses how oathtaking is fitting when we are dealing with particularly "weighty matters" or "vital affairs," which is the case with medicine, just as with getting married (when it involves a vow rather than merely a contract), assuming a public office, providing legal testimony, and entering religious life (124). He writes: "[Medicine] addresses our susceptibility to illness, decline, and death and our associated need for therapy. Caring for humans as beings subject to wounds - vulnerableconstitutes a weighty doing; medicine has the gravity necessary for the solemn practice of oathtaking. Hence, physicians fittingly take oaths" (125). Indeed, we can and should say that these weighty matters are weighty precisely because they concern the sanctity of human life, and thus we rightly recognize medicine as a solemn undertaking, as having real gravitas.

But again I think this requires recovering and defending a "religious sensibility" (or quasi-religious sensibility) that "forswears killing (including inchoate human life)" because of recognizing something sacred or reverence-worthy about human life. Elizabeth Anscombe gets at something like this when she writes about a "religious attitude" of "respect before the mystery of human life" - or what I would call the sacredness or reverence-worthiness of human life - which she says is "not necessarily connected only with some one particular religious system." Anscombe goes on to remark: "A religious attitude may be merely incipient, prompting a certain fear before the idea of ever destroying a human life, and refusing to make a 'quality of life'

${ }^{5}$ Leon Kass writes that on the Hippocratic view "the doctor is nature's cooperative ally and not its master" (1985: 234). 
judgment to terminate a human being. Or it may be more developed, perceiving that men are made by God in God's likeness, to know and love God" (2005: 269-270). Elsewhere she also speaks of "mystical perception," which is another way of articulating a "religious attitude" toward human life, or what we can also call a sense of the sacred or the reverence-worthy. Anscombe thinks that this perception is in fact "as common as humanity": for example, we find it in the perception that we dishonor our bodies in casual sex, in our sense that we owe respect to someone's dead body, and in our horror at the evil of murder (2008: 186-187). ${ }^{6}$ If we take the last example, the evil of murder (that is, the intentional taking of innocent human life), the claim is that we cannot make sense of this evil simply in terms of how it robs someone of future enjoyable experiences or how it violates someone's autonomy; rather, the horror of this evil is that it violates the profound intrinsic value of human life, that is, it violates that which should be regarded as inviolable. The general point is that we need a religious (or quasi-religious) sensibility regarding the sanctity of human life to make sense of common moral judgments.

The case for not taking early ("inchoate") human life can be more challenging. Although I think this is required by a belief in basic human equality (that is, a belief that all human beings, despite their manifold differences, possess the same fundamental dignity, or respect-worthiness, or "moral status"), which is widely though not always consistently professed today, ${ }^{7}$ it is nevertheless the case that many people have difficulty seeing early human life as being fully amongst us. Here I think we need to cultivate a sense of awe and reverence before the sheer fact of human existence, which again is a kind of religious or quasi-religious sensibility.

One writer who has sought to articulate this sensibility is G. K. Chesterton. In his most well-known book, Orthodoxy, he writes: "[The] things common to all men are more important than the things peculiar to any men. ... Man is something more awful than men; something more strange. The sense of the miracle of humanity itself should be always more vivid to us than any marvels of power, intellect, art, or civilization. The mere man on two legs, as such, should be felt as something more heartbreaking than any music and more startling than any caricature" (1986 [1908]: 249-250). In other words, there is a wondrous preciousness to human life as such, and the "miracle of humanity" is that we should exist at all. Or, as we might also put it, the wonder is that there should be a universe and that it should give rise to beings with rational natures, that is, that we should be the part of the universe that is able to stand up, look around, reflect upon the world, and appreciate it. ${ }^{8}$ There is surely here - if anywhere - something worthy of awe and reverence. Later in Orthodoxy Chesterton also brings out the sheer gratuitousness and wondrous preciousness of existence when discussing Robinson Crusoe. He says that his favorite part of the novel is the list of things that were saved from the wreck of Crusoe's ship, and he comments: "It

\footnotetext{
${ }^{6}$ I am indebted to Cora Diamond (2017) for bringing these Anscombe passages to my attention.

${ }^{7}$ On this point, consider again Anscombe: "[A] woman of today may find a possibility of becoming pregnant, letting the baby grow to twenty eight weeks (because bigger ones are worth more) and then going somewhere where they will pay her for a late abortion, which yields the foetus for resale, say, as valuable material. If you act so, are you not shewing that you do not regard that human being with any reverence? Few will fail to see that. But the same is true of one who has an abortion so that she can play in a tennis championship; or for any reason for which someone might choose to destroy the life of a new human being. This lack of reverence, of respect for that dignity of human nature so wonderfully created by God, is a lack of regard for the one impregnable equality of all human beings. Lacking it, you cannot revere the dignity of your own human-ness, that is the dignity of that same human nature in yourself. You may value yourself highly as a tennis player or a natural scientist, but without a change of heart you cannot value yourself as being a human, a Mensch. For you have shewn the value you set on a human life as such. You are willing to extinguish it as suits you or as suits the people who want you to do so" (2005: 72).

${ }^{8}$ I am echoing Kurt Vonnegut here: "I was some of the mud that got to sit up and look around" (1963: 221). I thank John Houston for this reference.
} 
is a good exercise, in empty or ugly hours of the day, to look at anything, the coal-scuttle or the book-case, and think how happy one could be to have brought it out of the sinking ship on to the solitary island. But it is a better exercise still to remember how all things have had this hairbreadth escape: everything has been saved from a wreck [that is, non-existence]. ... Men spoke much in my boyhood of restricted or ruined men of genius: and it was common to say that many a man was a Great Might-Have-Been. To me it is a more solid and startling fact that any man in the street is a Great Might-Not-Have-Been" (267). And if we can say this of any human being in the streets, then we can also say this of any human being in the womb.

Another important way to cultivate this sort of religious (or quasi-religious) sensibility that is properly responsive to the claims of the sanctity of human life in the practice of medicine is precisely through taking the Hippocratic Oath (or a contemporary version of it that is faithful to its enduring moral message) and seeking to live out the medical profession founded upon it. In other words, the Oath and the medical profession that arises from it are not simply based on a belief in the sanctity of human life, but rather the sense of solemnity that it cultivates also helps us better to appreciate the sanctity of human life. The Oath and the profession following from it are revelatory; they enable a transfigured vision whereby the reverence-worthiness of human life can come into view. This is a revelation that depends upon enactment of this reverenceworthiness through treating human beings as reverence-worthy.

\section{Medicine and Philosophy}

I want to conclude here by briefly examining the connection between medicine and philosophy (as understood by the ancients), which is relevant to the case I have made for seeing piety as the key virtue of medical practice. In his Decorum, Hippocrates himself highlights the connection:

Between medicine and the love of wisdom [that is, philosophy] there are no great differences; in fact medicine has all the things that lead toward wisdom: dislike of money, reverence, modesty, reserve, sound opinion, judgment, calm, steadfastness, purity, knowing speech, knowledge of things useful and necessary for life, dispensing of that which cleanses, freedom from superstition, pre-eminence divine. (cited in Kass 1985: 224)

According to its ancient Greek conception, philosophy is a "way of life"; indeed, it is a kind of "spiritual exercise," which involves "care of the soul" through examination of one's life and the world in which we live (see Hadot 1995; 2004). The philosopher seeks wisdom, that is, holistic understanding that is expressed in living well, which requires a transformation of being and of vision. In the case of medicine, the focus is on "care of the body," but, as Hippocrates indicates, this cannot be entirely separated from care of the soul (that is, the psyche). Etymologically, to heal is to make whole, and we cannot be whole while attending only to the body, or only to the soul; we must attend to both. ${ }^{9}$ Dealing with disease and injury raises questions of an existential or spiritual nature that need to be addressed: for example, questions about the meaning and value of human existence (see Sulmasy 2006: 16-17). Hence, medicine too must seek wisdom and should be regarded as a way of life and a kind of spiritual exercise; it is a way of life, I have suggested, that is guided by the virtue of piety (or reverence). Indeed, Hippocrates suggests that

\footnotetext{
${ }^{9}$ In fact, there is an etymological connection with "the holy" as well, and Kass remarks: "The insight that drew the holy, the healthy, and the whole from a common etymological root may point to the deepest wisdom, not only for medicine but perhaps also for how we are to live" (1985: 246).
} 
both medicine and philosophy properly understood are guided by reverence, and this certainly seems true for many of the great ancient philosophers. ${ }^{10}$ Hippocrates says that reverence leads to wisdom, though it is also part of wisdom to recognize what is reverence-worthy and to be properly responsive to it. In the foregoing I have suggested that the wisdom upon which the Hippocratic ethic ultimately depends includes a cultivated sense of awe and reverence before human life, and undertaking the Oath and living it out can be an important part of cultivating such wisdom about our existence.

\section{References}

Anscombe, G. E. M. (2005). Human life, action and ethics: Essays by G. E. M. Anscombe, M. Geach and L. Gormally (eds.). Charlottesville, VA: Imprint Academic.

Anscombe, G. E. M. (2008). Faith in a hard ground: Essays on religion, philosophy and ethics by G. E. M. Anscombe, ed. M. Geach and L. Gormally. Charlottesville, VA: Imprint Academic.

Cavanaugh, T. A. (2018). Hippocrates' oath and Asclepius' snake: The birth of the medical profession. Oxford: Oxford University Press.

Chesterton, G. K. (1986 [1908]). Orthodoxy. In The collected works of G. K. Chesterton, vol. I. San Francisco, CA: Ignatius Press.

Diamond, C. (2017). The problem of impiety. In D. McPherson (ed.), Spirituality and the good life: Philosophical approaches (pp. 29-46). Cambridge: Cambridge University Press.

Hadot, P. (1995). Philosophy as a way of life: Spiritual exercises from Socrates to Foucault, A. Davidson (ed.), M. Chase (tr.). Oxford: Blackwell Publishing.

Hadot, P. (2004). What is ancient philosophy?, Michael Chase (tr.) Cambridge, MA: The Belknap Press of Harvard University.

Kass, L. R. (1985). Toward a more natural science: Biology and human affairs. New York: The Free Press.

Kass, L. R. (2002). "I will give no deadly drug": Why doctors must not kill. In K. Foley and H. Hendin (eds.). The case against assisted suicide: For the right to end-of-life care (pp. 1740). Baltimore, MD: The Johns Hopkins University Press.

McPherson, D. (2018). Transfiguring love. In F. Ellis (ed.), New models of religious understanding (pp. 79-96). Oxford: Oxford University Press.

McPherson, D. (2020). Virtue and meaning: A neo-Aristotelian perspective. Cambridge: Cambridge University Press.

Pellegrino, E. D., \& Thomasma, D. C. (1993). The virtues in medical practice. Oxford: Oxford University Press.

Pellegrino, E. D., \& Thomasma, D. C. (1996). The Christian virtues in medical practice. Washington, DC: Georgetown University Press.

Roberts, R. C. (2017). The virtue of piety. In D. McPherson (ed.), Spirituality and the good life: Philosophical approaches (pp. 47-62). Cambridge: Cambridge University Press.

\footnotetext{
${ }^{10}$ Consider these remarks from Hadot on one instance: "[For] Aristotle the life of the mind consists, to a large degree, in observing, doing research, and reflecting on one's observations. Yet this activity is carried out in a certain spirit, which we might go so far as to describe as an almost religious passion for reality in all its aspects, be they humble or sublime, for we find traces of the divine in all things" (2004: 82). As Aristotle puts it in Parts of Animals: "In all natural things there is something wonderful" (645a18; trans. I. D. M. Balm).
} 
Sulmasy, D. (2006). The rebirth of the clinic: An introduction to spirituality in health care. Washington, DC: Georgetown University Press.

Vonnegut, K. (1963). Cat's cradle. New York: Dial Press. 